\title{
Carrier Sanctions in Europe: A Comparison of Trends in 10 Countries
}

\author{
Theodore Baird \\ vu Amsterdam, De Boelelaan 1105, 1081 HV, Amsterdam, the Netherlands \\ tedbaird@gmail.com
}

\begin{abstract}
Carrier sanctions are penalties given to transport companies if they carry improperly documented passengers. While the literature on carrier sanctions grapples primarily with comparative legal and normative questions surrounding asylum-seeking and democratic accountability, the empirical material covering the implementation of carrier sanctions is more limited. None of the literature to date has examined the statistical trends in the enforcement of carrier sanctions by European states. This article fills this gap and provides the first comparative analysis of statistics on the yearly number and costs of carrier sanctions. Through a new dataset on the implementation of carrier sanctions in 10 European countries between 2000-2014, the data reveal a puzzling variation in carrier sanction implementation over time, with wide variation among states, due in part to the un-reliability of the data. These variations are discussed in the context of current legal, political, and migratory trends in Europe.
\end{abstract}

* I owe a huge debt of gratitude for assistance with translation, interpretation, and research support to: Jill Alpes, Nefeli Bami, Cristina del Biaggio, Paolo Cuttitta, Panos Hatziprokopiou, Segolene Mennesson, Emanuela Roman, Thomas Spijkerboer, Orcun Ulusoy, and Ignacio Urquijo. Special thanks to Banafsheh and Judith at vu for helping with referencing. Thank you for your assistance in carrying out this research. I also want to give special thanks to all the respondents and others who assisted with locating sources, I am reluctant to name all of you, but your assistance made data collection much smoother and interesting. I would also like to thank the members of the advisory board meeting for the Human Costs of Border Control project, where this work was first presented. A final thanks to the anonymous referee who provided critical comments which improved the paper. Thank you for the comments and discussion. Research for this article was conducted as part of the project 'Border Policies and Sovereignty: Human Rights and the Right to Life of Irregular Migrants,' supported by Dutch NWO Vici grant number 016.130.061.

(C) THEODORE BAIRD, 2017 | DOI 10.1163/15718166-12340009

This is an open access article distributed under the terms of the prevailing CC-BY-NC license at the time of publication. 


\section{Keywords}

carrier sanctions - privatization - externalization - European Union

Carrier sanctions, whereby private carriers are sanctioned for transporting undocumented travellers, are a fundamental 'remote control' measure of states and are one of the leading examples of the privatization of migration management. ${ }^{1}$ Carriers are obligated to check whether passengers have the required documents for entry into state territory, and are fined when carrying passengers with inadequate documentation. Since checks are carried out in ports of departure, carrier sanctions remain a quintessential form of extraterritorial migration control.

Carrier sanctions are only one 'flanking measure' used to deter irregular migration to Europe. Other measures, forming a 'buffer zone', include visa policies, Immigration Liaison Officers posted in third countries, the criminalization of facilitation, active surveilling and policing of the external land, sea, and air borders, maritime interception, and cooperation and regional agreements with third countries and organizations. ${ }^{2}$ Carrier sanctions are one type of 'passive' non-arrival policy, related to visa regimes and pre-entry clearance, as opposed to 'active' non-entry policies such as maritime interception. ${ }^{3}$ Carrier sanctions are most closely related to visa regimes, as visa regimes are in part enforced through carrier sanctions, as private carriers impose more levels of screening documents. ${ }^{4}$

Research on carrier sanctions has filled a niche within migration studies, attracting the attention of scholars working on the privatization and

1 Scholten, S. \& P. Minderhoud, 'Regulating Immigration Control: Carrier Sanctions in the Netherlands', 10(2) European Journal of Migration and Law (2008) 123-147.

2 Brouwer, A. \& J. Kumin, 'Interception and Asylum: When Migration Control and Human Rights Collide', 21(4) Refuge (2003) 6-24; Collinson, S., 'Visa Requirements, Carrier Sanctions, "Safe Third Countries" and "Readmission": The Development of an Asylum "Buffer Zone" in Europe', 21(1) Transactions of the Institute of British Geographers (1996) 76-90; Sianni, A., 'Interception Practices in Europe and Their Implications', 21(4) Refuge (2003) 25-34.

3 Goodwin-Gill, G.S. \& J. McAdam, The Refugee in International Law, 3rd edition (Oxford: University Press, 2007).

4 Dunstan, R., 'United Kingdom: Breaches of Article 31 of the 1951 Refugee Convention', 10(1/2) International Journal of Refugee Law (1998) 205-213, at 209. 
externalization of migration controls. Research on carrier sanctions has focused on two main strands: (1) Comparative work on the privatization and outsourcing of migration management to third parties and (2) Legal and ethical analyses focusing on international law and the human rights implications of externalization for international protection.

Comparative work has provided fruitful comparisons of the development of carrier sanctions in Europe; ${ }^{5}$ describing them as a type of third party liability system with implications for discretion and democratic control; ${ }^{6}$ placing them in the context of geopolitics of border controls and interception measures; ${ }^{7}$ understanding them in relation to globalization and state sovereignty; ${ }^{8}$ explaining their role in political economy and rising neo-liberalization; ${ }^{9}$ probing the rise of carriers as 'experts'; ${ }^{10}$ and understanding shifts in sanctions with regulation and governance perspectives. ${ }^{11}$ The Determinants of International Migration (DEMIG) database tracks policy changes with regard to carrier

5 Cruz., A., 'Carrier Sanctions in four European Community States: Incompatibilities Between International Civil Aviation and Human Rights Obligations', 4(1) Journal of Refugee Studies (1991) 63-80; Cruz, A., Carriers Liability in the Member States of the European Union, Churches Commission for Migrants in Europe (ССмE) Briefing Paper no. 17 (Brussels: CCME, 1994).

6 Gilboy, J.A., 'Implications of "Third-Party" Involvement in Enforcement: The INs, Illegal Travelers, and International Airlines', 31(3) Law \& Society Review (1997) 505-530; Guiraudon, V. 'Enlisting Third Parties in Border Control: a Comparative Study of its Causes and Consequences', in: M. Caparini \& M. Otwin (Eds), Borders and Security Governance: Managing Borders in a Globalised World (Geneva, Zürich and Münster: Centre for the Democratic Control of Armed Forces (DCAF), Lit Verlag GmbH \& Co. KG Wien and Lit Lektorat, 2006).

7 Collinson, S., 'Visa Requirements, Carrier Sanctions, "Safe Third Countries" and "Readmission": The Development of an Asylum "Buffer Zone" in Europe', 21(1) Transactions of the Institute of British Geographers (1996) 76-90.

8 Guiraudon, V. \& G. Lahav, 'A Reappraisal of the State Sovereignty Debate: The Case of Migration Control', 33(2) Comparative Political Studies (2000) 163-195.

9 Menz, G. 'Neo-liberalism, Privatization and the Outsourcing of Migration Management: A Five-Country Comparison', 15(2) Competition and Change (2011) 116-135.

10 Scholten, S. \& A. Terlouw, 'Private carriers as experts in immigration control', in: M. Ambrus, K. Arts, E. Hey \& H. Raulus (Eds), The Role of 'Experts' in International and European Decision-Making Processes: Advisors, Decision Makers or Irrelevant Actors? (Cambridge: University Press, 2014).

11 Scholten, S. The Privatisation of Immigration Control through Carrier Sanctions: The Role of Private Transport Companies in Dutch and British Immigration Control (Leiden: Koninklijke Brill NV, 2015); Scholten \& Minderhoud, 2008 (n. 1). 
sanctions, and finds that they have become more restrictive over the years of coverage. ${ }^{12}$

In the literature on legal aspects of carrier sanctions, there is a general consensus among researchers that they are harmful to international legal and human rights obligations, a form of unjustifiable coercion, and overall contribute to increased risks to populations in search of protection. ${ }^{13}$ Carrier sanctions have had the effect of deterring asylum-seekers and restricting the rights of refugees. ${ }^{14}$ Feller argues that carrier sanction legislation is "fundamentally flawed" as it undermines basic principles of refugee protection..$^{15}$ UNHCR, Amnesty International, and ECRE each provided their reservations towards the policy in the $1990 \mathrm{os} .^{16}$ Cruz's comparative work found a number of incompatibilities of carrier sanctions with legal and human rights obligations in Belgium, Denmark, Germany, and the UK. ${ }^{17}$ Lax demonstrates, with regard to the Common European Asylum System (CEAS), that "passive interception

12 DEMIG, 2015.

13 Amnesty International, No Flights to Safety: Carrier Sanctions; Airline Employees and the Rights of Refugees, Amnesty International, International Secretariat, November 1997 (AI Index: ACT 34/21/97, Distr: SC/RC) (London: AI,1997; Bloom \& Risse, 2014 (n. 21); Collinson, 1996 (n. 7); Cruz, 1991 (n. 5); Feller, E., 'Carrier Sanctions and International Law', 1(1) International Journal of Refugee Law (1989) 48-66.; Goodwin-Gill \& McAdam, 2007 (n.3)), p. 371,177; Lax, V.M., 'Must E U Borders have Doors for Refugees? On the Compatibility of Schengen Visas and Carriers' Sanctions with EU Member States' Obligations to Provide International Protection to Refugees', 10 European Journal of Migration and Law (2008) 315-364, at 362; Rodenhauser, T., 'Another Brick in the Wall: Carrier Sanctions and the Privatization of Immigration Control', 26(2)International Journal of Refugee Law (2014) 223-247; Scholten, 2015 (n. 11); UNHCR, UNHCR Position: Visa Requirements and Carrier Sanctions (Geneva: UNHCR, 1995).

14 Gorlick, B., 'Refugee Protection in Troubled Times: Reflections on Institutional and Legal Developments at the Crossroads', in: N. Steiner, M. Gibney \& G. Loescher (Eds), Problems of Protection: The UNHCR, Refugees, and Human Rights (New York and London: Routledge, 2003) pp. 79-100, at 86. Helton, A.C. 'What is Refugee Protection? A Question Revisited', in: N. Steiner, M. Gibney \& G. Loescher (Eds), Problems of Protection: The UNHCR, Refugees, and Human Rights (New York and London: Routledge, 2003) pp. 19-33.

15 Feller, 1989 (n. 13).

16 UNHCR, 1995 (n. 13); Amnesty International, 1997 (n. 13); ECRE, Carriers' Liability: Country up-date on the application of carriers' liability in European States, European Council on Refugees and Exiles (ECRE) Research paper (Brussels: ECRE, 1999).

17 Cruz, 1991 (n. 5); Cruz, 1994 (n. 5). See also for the U K: Nicholson, F., 'Implementation of the Immigration (Carriers' Liability) Act 1987: Privatising Immigration Functions at the Expense of International Obligations?', 46(3) International and Comparative Law Quarterly (1997) 586-634. 
measures" like carrier sanctions "may, under certain conditions, breach the requirements of human rights law."18 The Carrier Sanctions Directive has been criticized because it does not provide appropriate safeguards against refoulement, nor access to remedies for those who have been refused boarding. ${ }^{19}$ According to Gammeltoft-Hansen, "carrier sanctions today constitute a primary tool for ensuring pre-arrival migration control and a major obstacle for many migrants and refugees to reach the territory of their prospective destination state by regular travel." ${ }^{20}$ Bloom and Risse argue that carrier sanctions represent a form of 'hidden coercion' at international borders which is unjustifiable. ${ }^{21}$

While these two strands of literature provide us with a solid ground on which to explain and scrutinize carrier sanctions in comparative contexts, none of these works have engaged in a comparison of carrier sanction data using available statistics of trends in fines, and trends in the amount of fines are often presented in isolation. Empirical studies explaining the development of carrier sanctions, their implementation, and their impacts suffer from limited data and small-n case studies. This article attempts to fill some of the gaps in the literature by analyzing a novel data set of trends from across Europe that is neither comprehensive nor unproblematic. The dataset is comprised of figures from 10 European countries on the number and amount of carrier sanctions levied. Given the difficulties in collecting the limited primary quantitative data available on the topic, the statistical trends are supplemented with qualitative interviews and socio-legal analysis of documents and secondary data. One of the major issues that arose from the work is the (un)reliability and variable quality of the data, which have impacted the discussion and results (see more below in the Methods section).

This article asks: How have carrier sanction trends changed between 20002014? What have been the causes of these trends? A number of sub-questions arise: How many fines are given each year? How much is paid? What do trends reveal about carrier sanctions in particular states, and do these trends tell us anything about the causes and effects of carrier sanctions?

$18 \operatorname{Lax}, 2008$ (n. 13) 362.

19 Sianni, 2003 (n. 2) 27.

20 Gammeltoft-Hansen, T. 'The rise of the private border guard: Accountability and responsibility in the migration control industry', in: T. Gammeltoft-Hansen \& N.N. Sorensen (Eds), The Migration Industry and the Commercialization of International Migration (Abingdon and New York: Routledge, 2013).

21 Bloom, T. \& V. Risse, 'Examining hidden coercion at state borders: why carrier sanctions cannot be justified', 7(2) Ethics \& Global Politics (2014) 65-82. 
The paper begins by outlining the methods used to gather the statistics on carrier sanctions and the main challenges faced during collection. It then describes the main statistics before turning to a discussion of the variation in trends. It concludes with theoretical and normative implications, providing suggestions for future research.

\section{2 Methods}

Lack of reliable and valid data plagues research on carrier sanctions, even while the practice has a significant impact on the rights of asylum-seekers and migrants. This section highlights the difficulties in collecting data on carrier sanctions in Europe. ${ }^{22}$ It also elaborates on difficulties in inferring from unreliable and incomplete data.

\section{Why Compare Statistics on Carrier Sanctions?}

First, there are no collated data available on trends in fines over time. Evidence for carrier sanction trends is severely limited, and researchers thus have limited understandings of how carrier sanctions are implemented over time. Collecting and analyzing such statistics gives insight into the implementation of migration control regulations and the privatization of control in Europe, an area hampered by limited transparency and accountability. ${ }^{23}$ Second, there are no EU or national systems in place that monitor or evaluate the enforcement of carrier sanctions legislation. Quantitative and/or qualitative assessments of the implementation and impacts of carrier sanctions legislation do not exist (with minor exceptions looking at the transposition of legislation into national law). ${ }^{24}$ Such data could prove useful in evaluating the human rights impacts of carrier sanctions. Third, trends in carrier sanctions statistics are proxy data for understanding transformations and changes in border control practices in European countries. Such statistics may provide further evidence for the

22 This section draws on questions and themes arising from the Roundtable Event "If You Don't Count, You Don't Count," organized by Tamara Last and the Migration and Diversity Centre at vU Amsterdam, 21.6.2016.

23 Gammeltoft-Hansen, 2013 (n. 20), p. 130.

24 Hailbronner, K. \& C. Carlitz, Directive 2001/51 Carriers Liability Synthesis Report. Study on the 'Conformity checking of the transposition by Member States of 10 EC Directives in the sector of Asylum and Immigration' done for DG JLS or the European Commission, Contract JLS/B4/2006/o3 (Brussels: Academic Network for Legal Studies on Immigration and Asylum in Europe, 2007). 
variations in growing restrictiveness or liberalization of migration controls. ${ }^{25}$ Finally, carrier sanctions statistics could tell us something about the politics of numbers in the governing of European external borders. By revealing what is and is not an "object of state knowledge" we can better understand how states produce statistics and what inclusions and omissions say about human rights aspects of border. ${ }^{26}$

The lack of publically available statistics on carrier sanction trends stems from a number of factors. There is no legal obligation to collect carrier sanction statistics. According to DG Home Affairs, DG Home does not systematically collect statistics on the number of penalties applied to carriers by Member States. ${ }^{27}$ Council Directive 2001/51 does not oblige Member States to collect, store, or share statistics with the Commission. Regulation 2007/862 on Community statistics on migration does not oblige Member States to share statistics on carrier sanctions with the Commission. States' national laws typically do not oblige authorities to collect carrier sanctions statistics.

Carriers are not required to publicize their sanctions. According to the Association of European Airlines, carriers do not keep separate statistics on fines imposed by Eu Member States, but do collect statistics on fines imposed that they receive worldwide. ${ }^{28}$ For a middle-sized airline (unnamed), for example, fines totalled 300,000 EUR in 2014. For a larger airline, a higher figure would be more likely. According to Czech Airlines, there are a number of reasons why carriers do not collect statistics on carrier sanctions: data are only kept for short periods of time, or are only recently collected, or simply do not exist; there is staff turnover within the organization, and different managers have different priorities, not valuing statistics on carrier sanctions; airlines have variable histories of adding international stations and experiences with international travelers, leading to variations in the types of statistics necessary to collect in order to drive business in these stations; there are no statistics because fines are new, and airlines are inexperienced with dealing with these fines; the data on sanctions have to be stored somewhere, and this costs money and time which organizations may not want to invest in; the requirements for handling documents and international passengers may be changing,

25 Haas, H. de, K. Natter \& S. Vezzoli, 'Growing Restrictiveness or Changing Selection? The Nature and Evolution of Migration Policies', International Migration Review, Early view: July 2016.

26 Aas, K.F. \& H.O.I. Gundhus, 'Policing Humanitarian Borderlands: Frontex, Human Rights and the Precariousness of Life', 55(1) British Journal of Criminology (2015) 1-18.

27 Personal communication, DG Home Affairs, 11.2.2014.

28 Personal communication, AEA, 3.9.2015. 
and airlines are having to adapt, with consistent statistics getting lost in the changes; statistics are not useful for training staff, and thus are not collected as they are not deemed necessary for operations; costs of fines are considered low compared to other potential sanctions, so airlines do not collect regular statistics as the budget line can be lumped together with other items (however, if there are too many fines, then it is necessary to re-think and check operations). ${ }^{29}$ Statistics are not always seen as important, for example KLM has articulated that addressing the reasons for the sanction are more important than the sanction itself. ${ }^{30}$ Finally, carriers which may be partly owned by the state have different relations with regulators than carriers which are wholly privately owned, raising the issue that statistics are not necessary for different kinds of organizations.

Both governments and carriers are 'reluctant' to release such numbers to avoid a negative public image or identify those passengers who have been rejected from traveling. ${ }^{31}$ Annual reports of major airlines do not cover such statistics, as revealing sanctions may impact investor relations. For example, International Airlines Group, which owns British Airways, Iberia, and Vueling, in their 2014 annual report, published for the first time the value of fines and sanctions for non-compliance with existing laws, while mentioning that 'historic data is unavailable. ${ }^{32}$ While the types of fines are disaggregated in the report, none of them are very specific and none refer to carrier sanctions in particular.

A lack of clarity regarding the competent authority leads to variations in availability. The competence for handling the sanction is split amongst multiple authorities in some cases. For example, after an email requesting data, I received a phone call from the Greek police headquarters to inform me that they are only partially competent to answer my questions regarding carrier sanctions. ${ }^{33}$ I spoke with a managing officer who did not have practical experience, but said that he would forward my requests for an interview to Civil Aviation and to the Border Police at Athens International Airport. The guard informed me that the police report the undocumented migrants to Civil

29 Personal communication with Czech Airlines, Airport Security Conference, Barcelona, 18.11.2015.

30 Personal communication, KLM, Airport Security Conference, Barcelona, 18.11.2015.

31 Gammeltoft-Hansen, 2013 (n. 20), p. 141.

32 IAG, 2014 Annual Report and Accounts, iairgroup.com, (London: International Airlines Group, n.d.), p. 3 .

Personal communication, Greek Police, 17.2.2014. 
Aviation, and then Civil Aviation orders the fine to the airlines. After the police report the undocumented migrants to Civil Aviation, their role is finished. After some more emails and phone calls, I was able to contact the competent authority in the Hellenic Civil Aviation Authority, who granted me the statistics by email (see Table of Sources).

\section{Selection of Case Studies}

The data I sought were the yearly number and amount of fines for select EU Member States from 2000 to 2014. Initially the case studies were limited to four Mediterranean countries - Spain, Italy, Malta, and Greece-in line with the cases included in the Human Costs of Border Control Project. ${ }^{34}$ However, difficulties in obtaining these statistics in these countries led me to search for statistics in other European states, both EU and non-EU. This led to a wider selection of case studies as it was easier in some countries (Sweden and Switzerland for example) to obtain statistics via personal communication than others. Some data were available publically online (such as in the uk and Germany). Availability of data raises questions of reliability, which I discuss below.

\section{Data Collection}

Collecting data on carrier sanctions requires personal communication with competent authorities and persistence in locating and extracting the appropriate data. A range of sources were used in this study: I approached the Commission and the Parliament (DG Home, DG Move, LIBE Committee, TRAN Committee); Member State Ministries and police agencies; Civil aviation authorities; state statistics agencies; non-governmental organizations; business federations and airline federations; and international organizations such as ICAO and IATA. The final sources used are available in Table 1.

Most organizations I contacted did not collect the data or referred me those authorities that did. I contacted competent authorities through Internet searches in multiple languages (English, French, Spanish, German, Italian) in order to identify the appropriate authority. I then trawled governmental websites for potential documents and publications which contained the appropriate data. Identifying the appropriate authority could be a hassle, as I would be referred to different authorities only eventually to be referred back to the original person I contacted. Once identifying the appropriate authority, I emailed them and/or made phone calls. 


\begin{tabular}{|c|c|c|}
\hline Country & Sources and interview dates & Coverage \\
\hline Germany & $\begin{array}{l}\text { Parliamentary Question: Zahl der Abschiebungen, } \\
\text { Zurückweisungen und Zurückschiebungen, Mitte } \\
2016 \text { (BT-Drs. 18/9173), Vermerk Dr. Thomas } \\
\text { Hohlfeld, Referent Fraktion DIE LINKE., 227- } \\
51122,5.8 .2016 \\
\text { Phone Interview: Bundespolizeipräsidium, } \\
\text { 16.11.2016 }\end{array}$ & $\begin{array}{l}\text { Unclear, primarily } \\
\text { Air }\end{array}$ \\
\hline France & $\begin{array}{l}\text { Personal Communication: Anafe, Email, } \\
22.11 .2016 \text {, for } 2006 \text { \& } 2014 \\
\text { Personal Communication: French Ministry of } \\
\text { Interior, } 24.01 .2017 \text {, for } 2012-2014\end{array}$ & $\begin{array}{l}\text { Air, possibly } \\
\text { Maritime }\end{array}$ \\
\hline Greece & $\begin{array}{l}\text { Personal Communication: } \\
\text { Hellenic Civil Aviation Authority, Email, 29.6.2016 }\end{array}$ & Air \\
\hline Spain & $\begin{array}{l}\text { Personal Communication: } \\
\text { Commisaria General de Extranjera y Fronteras, } \\
\text { Email, 9.8.2015 }\end{array}$ & Air, Maritime \\
\hline Italy & $\begin{array}{l}\text { Personal Communication: } \\
\text { Ministry of Interior, Central Directorate for } \\
\text { Immigration and Border Police, Email, 3.12.2015 }\end{array}$ & Air \\
\hline Malta & $\begin{array}{l}\text { Phone Interview: The Malta Police Force, } \\
\text { 5.2.2014 } \\
\text { Personal Communication: The Malta Police Force, } \\
\text { Email, 6.2.2014 }\end{array}$ & $\begin{array}{l}\text { Air, possibly } \\
\text { Maritime }\end{array}$ \\
\hline Netherlands & $\begin{array}{l}\text { Conference Presentation: } \\
\text { KLM, Airport Security Conference, Barcelona, } \\
18.11 .2015\end{array}$ & Air \\
\hline UK & $\begin{array}{l}\text { www.gov.uk, search term: 'carrier's liability', https:// } \\
\text { www.gov.uk/government/publications/number- } \\
\text { of-cases-and-fines-since-introduction-of-carrier- } \\
\text { sanctions-from-1987-to-2012 }\end{array}$ & Air, Maritime \\
\hline Sweden & $\begin{array}{l}\text { Personal Communication: Swedish Migration } \\
\text { Agency, Email, 22.3.2016 }\end{array}$ & Air \\
\hline Switzerland & $\begin{array}{l}\text { Personal Communication: Federal Department of } \\
\text { Justice and Police, State Secretariat for Migration, } \\
\text { Email, 24.3.2016 }\end{array}$ & Air \\
\hline
\end{tabular}


The data were not always complete, nor digitized (required the scanning of paper documents). The UK for example had comprehensive material online and searchable, while the material for Greece was only communicable via email. In a stroke of luck, I was emailed the statistics from Germany from a colleague, and corroborated through further emails with an NGO, which referred me to the final source. Data from the Netherlands could not be located even after a number of emails, but I was able to obtain some limited data from KLM from a public conference presentation. When possible I contacted relevant officials in the language of the country, using translations of colleagues when necessary (see Acknowledgements). Communication of the data was almost always accompanied by minor caveats and descriptions, and in some cases it was not clear what type of data I received, requiring multiple clarifications and corrections. For example, the data for Sweden may not be valid as it is unclear if the data are what was requested: there was a potential miscommunication issue with the provider, it was unclear if they understood the question asked in the email, and the issue was not resolved through further email. Furthermore, some sources were unclear if all transport types, or only airlines, are included in stats, and confirmations with the responsible sources were not responded to. I assume that the number of fines is primarily for air carriers, but this lack of assurance is a major limitation of the data.

After collection, the data were compiled to look for any patterns or identifiable trends. The data are patchy and incomplete, but the overall trends reveal that carrier sanction legislation is variably enforced across European countries: some countries see an increase in fines (like Germany), others a decrease (like the UK and NL), others remain roughly the same but with minor increases or decreases (such as Spain and Italy), and others have given effectively no sanctions (like Sweden and Switzerland) (see Table 2 for more detail).

\section{Issues with Data Collection and Analysis}

According to previous work by Guiraudon, a number of difficulties arise when trying to assess carrier sanctions: ${ }^{35}$

[C]ompanies are reluctant to give out information, government bodies rarely and parsimoniously release data on sanctions and seldom evaluate the implementation of the policy, even when required by law.... It is even impossible to see the penalties appear either as a credit in the state budget or as a debit in the companies' financial statements. 
Given the problematic nature of the data, there are risks of trying to explain unreliable and incomplete data. I have wherever possible supplemented the analysis with secondary sources and available academic analyses, but drawing conclusions from such un-reliable data is challenging. Are the trends described reliable representations of carrier sanctions in Europe or do the trends reflect more the ways in which states produce such data and how we as researchers collect such data? Do the trends reflect variable numbers of people entering Europe or do they reflect better reporting standards on behalf of the responsible authorities? Some data may be more reliable than other data due to variable reporting standards among countries, but it is difficult to make any conclusions about the reliability of the data without more detailed information. Answering the question whether some data is more reliable cannot be adequately addressed unless engaging in speculation. We can speculate that the UK and Germany have more reliable data because of their public availability and comprehensiveness, but Maltese data are also comprehensive but not public. For the other countries in the study, data were requested from authorities but were hard to access, scattered, and patchy. In consequence we cannot formally model and test hypotheses about the causes and effects of carrier sanctions. Cases are not selected randomly, but were selected by convenience and non-random. Thus, based on these issues, this study aims for an interpretive, hypothesis-generating, explorative account of variations in carrier sanctions, focusing on national trends.

\section{Description of Carrier Sanction Trends}

\section{Context}

Carrier sanctions statistics, however limited, cannot be judged in isolation. Contextual factors, such as volume of travelers and asylum-seekers, trends in routes, and alternative flanking measures help to place carrier sanctions within the European border control regime.

First, the volume of travelers to European territory is important for understanding the relative scale of sanctions. Passenger arrivals to EU territory have been increasing steadily between 2000 to $2015 \cdot{ }^{36}$ In $201437 \%$ of air passenger traffic to the EU-28 was extra-EU. ${ }^{37} 3^{21}$ million passengers required border checks in 2013, with arrivals from third countries into Schengen just over

36 Eurostat, Database, http://ec.europa.eu/eurostat/data/database (Brussels: European Commission, n.d.).

37 Eurostat, Air transport statistics, http://ec.europa.eu/eurostat/statistics-explained/index .php/Air_transport_statistics (Brussels: European Commission, 2015). 
109 million in the same year. ${ }^{38}$ With regard to the countries covered here, all saw increases in passenger arrivals. ${ }^{39}$

Second, trends in specific routes may provide clues as to the scale of sanctions. Passenger flow on entry to the EU is primarily by air, with land and sea taking second and third place respectively. ${ }^{40}$ London, Paris, Frankfurt, Amsterdam, and Madrid are the top five cities by volume of air passengers. ${ }^{41}$ Overall refusals of entry by air have decreased between 2008-2014, while passenger levels have increased across countries. ${ }^{42}$ Most refusals of entry at air borders were for Latin American nationalities, with eastern European and western Balkan countries being the most refused due to visa liberalization since $2011 .{ }^{43}$ However, $57 \%$ of air border refusals are from 'Other' countries. ${ }^{44}$ With regard to the countries covered in this study, all saw decreases in the number of refusals of third country nationals, with the exception of Italy, Greece, Malta, and Sweden. ${ }^{45}$ With regard to specific airlines refusing passengers along specific routes, comprehensive data are lacking. ${ }^{46}$

Third, the numbers of individuals applying for asylum in the EU has increased. Between 2008 and 2014, asylum applications rose from around 225 thousand to around 627 thousand, doubling in 2015 to 1.3 million. ${ }^{47}$ With regard to the countries covered here, there were increases in Germany, France, Italy, Spain, UK, the Netherlands, Sweden and Switzerland, with decreases in Greece and Malta between 2008 and 2014. ${ }^{48}$

\section{National Trends}

As Table 2 indicates, carriers face various levels of sanction for transporting improperly documented passengers. Unfortunately, the available statistics I collected are not disaggregated by nationality or origin of the carrier. Recall that the coverage of the statistics varies (see Table 1 above) and the numbers

38 Frontex, Annual Risk Analysis 2015. Warsaw: European Agency for the Management of Operational Cooperation at the External Borders of the Member States of the European Union, April 2015, Risk Analysis Unit, Frontex reference number: 4613/2015 (Warsaw: Frontex, 2015), p. 13.

39 Eurostat, n.d. (n. 36).

$40 \quad$ Frontex, 2015 (n. 38), p. 66.

41 Eurostat, 2015 (n. 37).

42 Frontex, 2015 (n. 38), p. 29.

43 Ibid.

$44 \quad$ Ibid, p. 6 o.

45 Eurostat, n.d. (n. 36).

46 Although some trends can be found in Guiraudon, 2006 (n. 6), p. 85.

47 Eurostat, n.d. (n. 36).

48 Ibid. 
TABLE 2 Number of fines for air carriers in Europe 2000-2014

\begin{tabular}{|c|c|c|c|c|c|c|c|c|}
\hline \multirow[t]{2}{*}{ Year } & \multicolumn{8}{|c|}{ Country } \\
\hline & Germany & France & Greece & Spain & Italy & Malta & Netherlands & UK \\
\hline 2000 & & & & & & & 587 & 6897 \\
\hline 2001 & & & & & & & & 5392 \\
\hline 2002 & & & & & & & & 3844 \\
\hline 2003 & & & & & & & & 3775 \\
\hline 2004 & & & & & & 169 & & 2959 \\
\hline 2005 & & & & & & 143 & & 2437 \\
\hline 2006 & & 535 & & & & 157 & & 2343 \\
\hline 2007 & 9 & & & & & 131 & & 2414 \\
\hline 2008 & 326 & & & & & 42 & & 2430 \\
\hline 2009 & 728 & & & & & 47 & & 2387 \\
\hline 2010 & 910 & & & 257 & & 28 & & 1891 \\
\hline 2011 & 1048 & & $5^{8}$ & 314 & 402 & 18 & & 1605 \\
\hline 2012 & 1477 & 1812 & 93 & 448 & 378 & 40 & & 1342 \\
\hline 2013 & 1098 & 1560 & 71 & 289 & 435 & $5^{2}$ & 147 & \\
\hline \multirow[t]{2}{*}{2014} & 1208 & $1395 /$ & 114 & 320 & 435 & & & \\
\hline & & $155^{1}$ & & & & & & \\
\hline Percent- & $13322 \%$ & $161 \% /$ & $97 \%$ & $25 \%$ & $8 \%$ & $-69 \%$ & $-75 \%$ & $-81 \%$ \\
\hline age & & $190 \%$ & & & & & & \\
\hline \multicolumn{9}{|l|}{ Change } \\
\hline Trend & Increasing & Increasing & Increasing & Increasing & Increasing & Decreasing & Decreasing & Decreasing \\
\hline
\end{tabular}

SOURCES: SEE METHODS SECTION. FOR THE NETHERLANDS, DATA ARE FROM KLM ONLY. FOR SWEDEN, 10 TOTAL 2005-2014 AT STOCKHOLM ARLANDA AIRPORT. FOR SWITZERLAND, 0 (ALL CASES THROWN

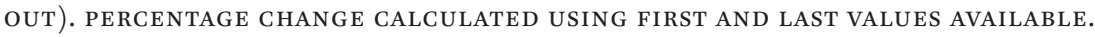

vary in part because of this differential coverage. We would expect carrier sanctions to go down, given that governments and airlines are working together more closely, but the trends vary, and the unreliability of the data adds to the aggravation in interpreting the trends. In this section I will describe the national trends, and in the next section I will discuss the possible reasons for this variability.

The German statistics reveal perhaps the most striking increase, with the number of fines increasing from 9 in 2007 to over 1200 in 2014. This rise occurs in the context of administrative restructuring within the police and new 
Memoranda of Understanding with airlines. ${ }^{49}$ Note that the coverage is unclear, but concerns primarily air carriers as discussed during communication with the Federal Police. The data for France have large gaps, but we can see a large increase between 2006 and 2014, and the data are inconsistent between respondents in 2014. The limited data from Greece indicate a rising trend, but a much more limited number of fines compared to Germany, France, and the UK. In Spain and Italy the data are slightly more comprehensive than Greece, and show a slightly rising trend which is perhaps indistinguishable from a stable trend. Note that Spain includes both maritime and air carriers. In Malta the trend is decreasing, with low numbers compared to the UK. For the Netherlands, the data only comes from KLM, a severe limitation given the size and volume of passengers passing through Schiphol Airport. Due primarily to a Memorandum of Understanding between the Dutch government and $\mathrm{KLM}$, the trend is clearly decreasing. In the $\mathrm{UK}$ the trend is decreasing the most dramatically across cases (although not as dramatic as the increase in fines in Germany), and represents the case with the highest numbers of all cases. The UK however provides numbers for all types transport across land, maritime, and air. For Sweden, there were 10 total cases only between $2005^{-2014}$ at Stockholm Arlanda Airport according to the source. The lack of data from other airports or at the national level hampers any reliable interpretation of the results. Finally, in Switzerland, all cases of carrier sanctions were thrown out, meaning there were effectively o cases.

\section{Estimating Costs}

The costs of a sanction can vary. Directive 2001/51 obliges Member States "to take the necessary measures to ensure that the penalties applicable to carriers ... are dissuasive, effective and proportionate" (Art. 4) (The Council of the European Union, 2001). Financial penalties shall be at minimum between 3,000-5,000 EUR per passenger, or a lump sum of 500,000 EUR, however "other measures involving penalties of another kind, such as immobilisation, seizure and confiscation of the means of transport, or temporary suspension or withdrawal of the operating licence" are not prohibited (Art. 5). National laws may provide for different sanctions, giving some variability in the amount across countries. ${ }^{50}$ The reported costs of sanctions are provided in Table 3.

49 Phone Interview: Bundespolizeipräsidium, 16.11.2016.

5o Hailbronner \& Carlitz, 2007 (n. 24), p. 29. 
TABLE 3 Reported costs of fines in select countries

\begin{tabular}{|c|c|c|c|c|c|}
\hline \multirow[t]{2}{*}{ Year } & \multicolumn{5}{|c|}{ Country } \\
\hline & Germany & France & Greece & UK & Netherlands \\
\hline 2000 & & & & $9,098,398$ & \\
\hline 2001 & & & & $7,35^{8,55^{1}}$ & \\
\hline 2002 & & & & $5,125,281$ & 560,000 \\
\hline 2003 & & & & $5,585,448$ & 333,405 \\
\hline 2004 & & & & $6,000,854$ & 760,000 \\
\hline 2005 & & & & $4,645,237$ & \\
\hline 2006 & & & & $4,296,700$ & \\
\hline 2007 & 9,000 & & & $4,623,380$ & \\
\hline 2008 & 326,000 & & & 4,628,00о & \\
\hline 2009 & $1,393,000$ & & & 3,986,0оо & \\
\hline 2010 & $1,577,500$ & & & $4,382,000$ & \\
\hline 2011 & $1,917,500$ & & 300,000 & $3,444,000$ & \\
\hline 2012 & $2,348,000$ & & 560,000 & $2,890,000$ & \\
\hline 2013 & $2,602,000$ & $7,270,322$ & $5,735,000$ & & \\
\hline 2014 & $2,634,500$ & $7,067,761$ & 770,000 & & \\
\hline
\end{tabular}

SOURCE: SEE METHODS SECTION. SOURCE FOR THE NETHERLANDS IS SCHOLTEN. ${ }^{51}$ ALL COSTS IN EUR EXCEPT FOR UK, WHICH IS IN GBP.

While we can see the costs of fines levied in Germany, France, Greece, the U K, and the Netherlands, we do not have access to the total costs of fines across Europe. Estimating the total costs of carrier sanctions across Europe is difficult, but a range can be obtained. According to the latest available numbers of sanctions in 2012, a year with almost comprehensive coverage, there were at least 5590 sanctions. If the costs of sanctions according to the Carrier Sanctions Directive are between 3000-5000 EUR, that means at minimum the costs for carrier sanctions in 2012 were 16,770,000-27,950,000 EUR. The costs for Germany, Greece, and the U K were around 6.3 million E UR in 2012. In 2006, the costs for 535 fines in France was 2,000,645 E UR. ${ }^{52}$ Thus, the minimum costs for compliance with carrier sanctions legislation across Europe are therefore

$51 \quad$ Scholten, 2015 (n. 11), pp. 166-167.

$5^{2}$ Personal Communication: Anafe, Email, 22.11.2016. 
high, but these numbers are highly speculative, and should be treated with caution because the amount of fines can vary.

The cost of individual sanctions is increasing according to the data, meaning that governments are attempting to gain compliance by increasing the severity of the cost of sanction. For example, while the number of sanctions are increasing in Germany, the cost per sanction is also increasing from $1000 \mathrm{EUR}$ per sanction in 2007 to $2181 \mathrm{EUR}$ in 2014. Alternatively, in the UK, with a decreasing trend in number of sanctions, the costs also increase from around 1319 G BP per sanction in 2000 to 2154 GBP in 2012. Penalties appear to be particular severe in the case of Greece and France, with low numbers but high costs (France increased costs for carrier sanctions in March 2016 under new reforms to the law on foreigners). According to an impact assessment of carrier sanctions in the UK, higher costs of sanctions "should act as an incentive to carriers to perform better document checks on their passengers" and "should lead carriers to rigorously enforce standards across all document processes and to also ensure they have an incentive to focus their effort on detecting document breaches". 53

The costs for transporters of implementing carrier sanctions are hard to obtain. Money is spent on "advising, monitoring, training, negotiating, and sanctioning". ${ }^{54}$ Menz notes that "[a]nnual expenditure for major European airlines on this aspect of migration management is in the mid-double digit millions of euros".55 Exact costs for these implementation efforts is not possible to calculate given the lack of data. However, we can make some rough estimates which should be treated with care. According to Scholten, in a discussion of the costs associated with the MoU, she cites respondents claiming that costs of implementation are roughly equivalent to the fines not imposed. ${ }^{56}$ If we subtract the number of fines given to KLM in 2000 from those given in 2013 (587-147), we have 440 fines 'not imposed', assuming the trend of fines would have remained stable without the MoU. Given that minimum costs for fines under Directive 2001/51 are between 3000-5000 EUR (note that these fines may be higher in national law depending on the category), then the estimated costs of implementation for KLM alone would at least be between 1.3-2.2 million EUR. Based on the costs of fines from 2002-2004, the average cost is possibly

53 The Home Office, Carriers' Liability Penalty Charge Consultation, Impact Assessment, Consultation, IA No: HOoo79(15/10/2012) (London: Home Office, 2012).

54 Scholten \& Minderhoud, 2008 (n. 1), p. 145.

55 Menz, G., 'Neo-liberalism, Privatization and the Outsourcing of Migration Management: A Five-Country Comparison', 15(2) Competition and Change (2011) 116-135, at 123.

$5^{6}$ Scholten, 2015 (n. 11), pp. 156-157. 
around 550,000 EUR. Assuming this average cost of fines remains stable, then costs of implementation between 2004-2014 would be around 550,000 EUR per year, or 5.5 million EUR. If we follow a similar logic for the UK, assuming fines remained stable and absent the MoU, costs of implementation for carriers in the period of 2000-2012 would hover around 6.2 million GBP. P\&O ferries, a major British cruise line traveling between France and the U $\mathrm{K}$, hired a private security firm to carry out checks which amounted to costs of 750,000 G BP per year. ${ }^{57}$ If we assume that the $750,000 \mathrm{GBP}$ costs for checks remained stable, then 10 year costs for implementation for $\mathrm{P} \& \mathrm{O}$ alone would be about 7.5 million GBP. Eurotunnel installed similar controls for trains but ferries were reluctant to transport Eurolines busses because of lack of these controls. During the period of the Sangatte camp, Eurotunnel estimated 15 million G BP in losses because of disruptions and closures, demanding that France close Sangatte. ${ }^{58}$ A tribunal involving Eurotunnel, France, and the UK found that the countries did not take appropriate security measures, and Eurotunnel claimed to have lost 30 million GBP due to expenses and damages, with France compensating 24 million GBP and Britain 8 million GBP in $2008-2009 .{ }^{59}$ The impact of Calais on carriers would have also been large. ${ }^{60}$ Given the unreliability of these minimum estimates, however, costs are likely to be much different.

Finally, costs for re-transporting inadmissible passengers can also be high. Scholten gives the example of a stowaway transported from Rotterdam harbor to Amsterdam Schiphol, with costs totalling 1200 EUR. ${ }^{61}$ In one case from 2013 where the carrier disputed the costs, the costs for re-transporting one passenger stood at 60,000 EUR. ${ }^{62}$ Costs for re-transporting $30-35$ people in 2007 amounted to $500,000 \mathrm{EUR}$ for KLM. ${ }^{63}$

4

\section{Discussion of Trends}

The causes of carrier sanction trends are variable and mixed and difficult to untangle. Scholten identifies a number of factors which impact how carrier

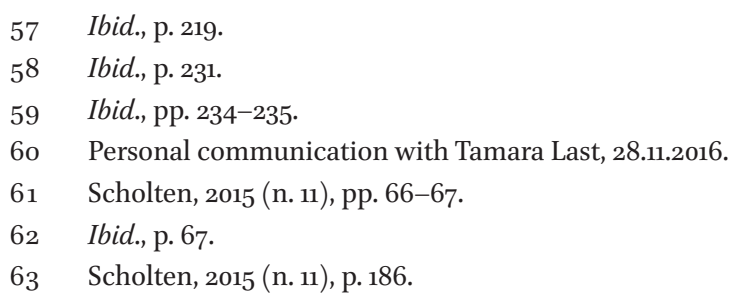


sanctions have been implemented. ${ }^{64}$ There has been (1) a shift from 'government regulation' to 'governance', reflecting "general trends in changing governing structures," with a diversity of tasks shifted from the state to private enterprises; (2) historical involvement of carriers in immigration control impacts current trends; (3) political pressure to tighten borders and gain 'access' to mobile populations. I discuss other trends briefly below which may have an impact of the variability of carrier sanction trends.

The cross-national variations are not easily explained due to the problematic nature of the data. In this discussion we must remain critical to these interpretations of why carrier sanctions are variable, but I do offer some hypothetical factors influencing the data which I have identified through interviews, primary sources, and secondary readings of the literature. However, the inferences we can draw from comparison are limited because cases were selected according to convenience, variation on the dependent variable (trends in fines) may not be reliable, and thus multiple causal factors can only be explored but not fully determined. Finally, discerning the effects of carrier sanctions is equally challenging, and I point to the secondary literature on its harmful effects in the introduction and conclusion.

\section{Legal Basis at EU and National Levels}

At the EU level, Article $26(\mathrm{lb} / 2)$ of the 1990 Schengen Implementation Agreement obliged all European Union Member States participating in Schengen to implement carrier sanctions, followed by the Carrier Sanctions Directive $(2001 / 51)$ in order to harmonize penalties. ${ }^{65}$ Directive 2001/51 regulates the issue of carriers transporting undocumented travellers, setting out the sanctioning scheme. ${ }^{66}$ At the national level, all countries in this study have transposed Directive 2001/51 (as a member of Schengen Switzerland is also bound by the Directive). ${ }^{67}$ However, some problems have arisen during transposition, as in Italy and Germany regarding the transposition of Articles 3

64 Scholten, 2015 (n. 11), p. 30.

65 Brouwer \& Kumin, 2003 (n. 2), pp. 6-24, at 9-10. The Schengen acquis - Convention implementing the Schengen Agreement of 14 June 1985 between the Governments of the States of the Benelux Economic Union, the Federal Republic of Germany and the French Republic on the gradual abolition of checks at their common borders, Official Journal L 239, 22/o9/2000 P. 0019-0062, http://eur-lex.europa.eu/LexUriServ/LexUriServ.do? uri=CELEX:4200oAog22\%2802\%29:en:HTML.

66 Personal communication with DG Home Affairs, 10.2.2014.

67 Hailbronner \& Carlitz, 2007 (n. 24), p. 14. 
and $4{ }^{68}$ Other countries with legal problems in transposition are Greece and Malta, and practical problems arise in the Netherlands and the UK. ${ }^{69}$

Directive 2001/51 gives some discretion to states to apply different standards when implementing carrier sanctions legislation. In addition, court decisions have shifted the reasoning of authorities giving fines. ${ }^{70}$ For example the German Federal Administrative Court has overturned fines because of a lack of legal basis for the government authority to issue fines. ${ }^{71}$ In the Netherlands, some cases have been dismissed and others settled out of court. ${ }^{72}$ Sanctions may in some cases be waived if the passenger is found to be a refugee. In the case of France, new legislation means that carriers originating in EU states cannot be fined. ${ }^{73}$ Thus, the variability of transposition, discretion given in the Directive, and court decisions, are bound to have some effect on the variability of fines given across countries.

\section{Administrative Structures of States}

Changes in the administrative structure of the responsible government authorities or carriers can have effect on the number of sanctions given. For example, in Germany, the reform of the Federal Police in 2008 led to the creation of new headquarters, centralized competencies, and a new unit dealing specifically with carrier sanctions. ${ }^{74}$ The result has been an increase in staff and the ability to better administer sanctions, increasing the number and amount of sanctions. In Malta authorities needed time to cope with the introduction of sanctions, resulting in a number a learning curve for authorities which took months to address. In other countries cooperation between carriers and governments created new structures of enforcement (see below). In other cases, a multitude of competent administrative structures may exist, or administrative structures may pass competence on to others without clear guidelines, meaning that sanctions are recorded across organizations and get lost, are lacking, or not well recorded, as in Spain, Greece, or Italy. Furthermore, streetlevel discretion is also likely to have an effect on the number of sanctions as in Switzerland or Sweden.

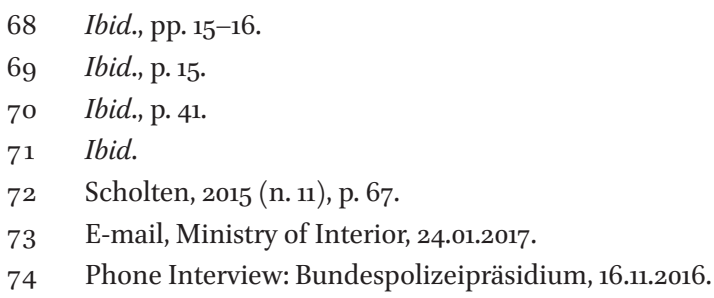


The size of firms operating carriers may also impact the number of sanctions, with larger and smaller companies suffering more or less sanctioning depending on the characteristic of the firm. ${ }^{75}$ Since most of the national air carriers have gone through restructuring and/or privatization during a period of liberalization and unification of the airline market in Europe, these processes of firm-level restructuring have likely had an effect on the variability of sanctions as carriers shift tasks and responsibilities across the organization. ${ }^{76}$ New carriers entering the market, such as low-cost carriers, is also likely to have an effect on the number and amount of fines, as these carriers have more or less experience with dealing with undocumented passengers. For example, in Italy, the airlines most sanctioned are from Alitalia and Ryan Air. ${ }^{77}$

\section{Business-Government Relations}

Business government relations in the context of carrier sanctions can have multiple effects on the number of sanctions given. For example, Memoranda of Understanding (MoUs) are important components of carrier-government cooperation. The 1944 Chicago Convention allows airlines to negotiate MoUs with states. ${ }^{78}$ The UK Home Office, in collaboration with carriers, has sought to decrease the number of fines through the negotiation of an MoU, an indication that carriers are becoming more proficient at controlling documents. Alternatively, in Germany, fines have increased even in the presence of MoUs, signalling that carrier-government collaboration can have mixed effects. According to a speaker from the UK Home Office, carriers are "critical partners," and carrier sanctions are not meant to increase costs to the airline industry, but to "prevent that bomb going off". 79 In the Netherlands, MoUs have been used to decrease the number of fines according to a quota system involving multiple categories of passengers. ${ }^{80}$

75 Scholten, 2015 (n. 11), p. 40.

76 Belobaba, P., A.R. Odoni, \& C. Barnhart, The global airline industry (Chichester, West Sussex: Wiley, 2009), p. 30 ff. Eurofound, 'Industrial relations in the airline sector', EurWORK (European Observatory of Working Life), 28 September 2005. (Dublin: European Foundation for the Improvement of Living and Working Conditions, 2005). Available online at: http://www.eurofound.europa.eu/observatories/eurwork/ comparative-information/industrial-relations-in-the-airline-sector.

77 Personal communication: Ministry of Interior, Central Directorate for Immigration and Border Police, E-mail, 3.12.2015.

78 Brouwer \& Kumin, 2003 (n. 2), p. 10.

79 Presentation by uk Home Office, 10.12.2014, 3rd World Borderpol Congress, Budapest, Hungary, December 2014.

$80 \quad$ Scholten, 2015 (n. 11), p. 154, see also p. 166 ff. 
Training of carriers can change the ability of carriers to be in compliance with government regulations and has likely led to variations in the amount of fines. The International Air Transport Association (IATA), representing the airline industry, has carried out trainings. ${ }^{81}$ According to an account by Dunstan, UK authorities "provided training, advice and technical support in respect of the detection of false travel documents to airline staff based at various points of embarkation," including donations and trainings to the Ethiopian Immigration Service and Ethiopian Airline staff. ${ }^{82}$

\section{States' Externalization Practices}

Carriers are often assisted by Immigration Liaison Officers, or other officials from the destination state stationed in the departure state, who assist carriers and border agents in conducting checks on documents through trainings and other operations. Other private security actors play a role in checking documents which may be removed from the carrier and the government. The plurality of regulatory authorities checking documents and acting as privatized agents of migration control signify that pre-entry clearances obliged by carrier sanctions serve as a de facto form of exit control, or the criminalization of emigration. ${ }^{83}$ Alpes' ethnographic material reinforces the hypothesis that preentry procedures, as obliged by carrier sanctions, block exit channels and push individuals towards irregular pathways. Variations in the discretion of migration control agents, whether public or private, lead to differing decisions during pre-entry clearance procedures, creating risks for vulnerable individuals. These pre-entry controls create real risks for individuals fleeing human rights abuses. Furthermore, her analysis suggests that the variability in numbers reflects discretionary practices of actors during pre-entry clearance, as people are prevented from flying from countries of departure where they may face abuse. New technologies of detecting fraudulent documents and stowaways is also likely to mediate the ability of governments to detected undocumented passengers, thus impacting the number of fines levied. Nevertheless, it is difficult to explain declining trends in carrier sanctions where privatization and externalization have increased.

\footnotetext{
81 Brouwer \& Kumin, 2003 (n. 2), p. 10.

82 Dunstan, 1998 (n. 4), p. 209.

83 Alpes, M.J., 'Airport Casualties: Non-Admission and Return Risks at Times of Internalized/ Externalized Border Controls', 4 Social Sciences (2015) 742-757; Alpes, M.J., 'Policing borders at airports: Public/private blurrings and the unifying force of fraud', in: T. Diphoorn \& E. Grassiani (Eds), Blurred Security: Anthropological perspectives on State and non-State Continuums. (forthcoming).
} 


\section{Carrier Practices}

Carrier practices which may impact the number and amount of sanctions relate to (1) heightened security measures and (2) discrimination towards certain social groups.

First, increased spending on security measures following 11 September 2001 attacks have impacted who participates in and how long check-in occurs. Guiraudon has shown how the blurring of public and private emerges in and through the hiring of former security forces by airlines: "the security agents hired by companies have either been trained by public agencies or are themselves former civil servants from the police forces, intelligence services or border police". ${ }^{84}$ Heightened security measures, and the involvement of multiple new actors (both private and public), have increased enplanement processing times, leading to long minimum check-in times and delays in boarding. ${ }^{85}$ International passengers, who are usually boarding larger planes, thus require much more processing time than domestic passengers. Capacity shortages and other irregularities in airport operations will thus impact who and when sanctions are levied. ${ }^{86}$ These measures have had a likely impact on carrier sanctions by distributing 'expert' knowledge across employees and increasing the number of necessary checks on passengers, leading to higher costs and the need to reduce sanctions. ${ }^{87}$

Second, discrimination is likely to play a role in the case of carrier sanctions, as well as profiling of suspected irregular migrants, by both carriers and governments. For example, when a group of Czech Roma asylum-seekers were refused to enter the UK at Prague Airport, no air carrier would carry them for risk of being fined. ${ }^{88}$ In another development, TAP Portugal suspended operations between Guinea-Bissau and Portugal, with a stop-over in Senegal, in December 2013, after 74 asylum-seekers from Syria with allegedly fake Turkish passports were allowed to board and subsequently claimed asylum in Portugal. ${ }^{89}$ TAP

84 Guiraudon, 2006 (n. 6), p. 82.

85 Belobaba et al., 2009 (n. 76)), p. 52.

86 Ibid., p. 253 ff.

87 Scholten \& Terlouw, 2014 (n. 10).

88 Battjes, H., Territoriality and asylum law: The use of territorial jurisdiction to circumvent legal obligations and human rights law responses, Working Paper, (n.d.), p. 14; Regina v. Immigration Officer at Prague Airport and Another, Ex parte European Roma Rights Centre and Others, [2004] UKHL 55, United Kingdom: House of Lords (Judicial Committee), 9 December 2004, available at: http://www.refworld.org/docid/41c17ebf4.html.

89 Bratley, Carrie-Marie, 'TAP suspends flights to Guinea-Bissau', The Portugal News Online, 11.12.2013, http://theportugalnews.com/news/tap-suspends-flights-to-guinea-bissau/ 30128; TAP Portugal,'TAP Special Operation to Bissau via Dakar ends December 2013', 
claims that the airline was forced to board the asylum-seekers by the Guinean authorities, while the Guinean authorities claim that the passports appeared genuine and the passengers cleared border controls. ${ }^{90}$ We can infer that TAP cancelled the route in fear of receiving sanctions for transporting more asylumseekers from this route. ${ }^{91}$ It is interesting to note that TAP has been accused in the past of discriminating on the basis of race and nationality. ${ }^{92}$ Finally, with regard to profiling, Emirates advocates that 'document check teams' cooperating internationally with border control authorities, coupled with sophisticated anti-counterfeit technologies, can be the solution to improperly documented travelers. ${ }^{93}$ As part of this strategy, "there tends to be an emphasis on profiling due to the volume of passengers and time constraints." According to Emirates, carrier sanctions "are designed to have a two-fold effect-acknowledging the responsibility of airlines and driving the borders to the point of acceptance at the last point of departure." 94

\section{Political Pressures}

Public opinion about migration is likely to shape the severity and amount of fines. In countries such as Sweden, which is publically more open to receiving migrants $(78 \%$ of Swedish respondents have positive feelings towards immigration from countries outside the European Union), the number of sanctions was low. ${ }^{95}$ In the UK, where the government is keen to reduce the number of undocumented travelers, and $49 \%$ of the public view immigration positively, numbers are high. ${ }^{96}$ In Germany, the numbers are increasing due to increased efficiency in administering sanctions as well as a highly charged political debate, yet $62 \%$ of the public view immigration

26.12.2013, http://www.tapportugal.com/PressRelease/en/tap-special-operation-tobissau-via-dakar-ends-december-2013.

9o Portugal Resident, 'Syrian asylum seekers detained in Portugal', 11.12.2013, http://portugal resident.com/syrian-asylum-seekers-detained-in-portugal.

91 Personal Communication with Tamara Last, 6.2.2014.

92 Guiraudon, 2006 (n. 6), citing: Cruz, 1994 (n. 5).

93 Al Hashimi, Abdulla, 'Travel Document Security: an airline perspective', Aviation Security International, June 2010, p. 20, http://content.yudu.com/A1o23n/ASIIssue 3June10/resources/index.htm?referrerUrl=http\%3A\%2F\%2Fwww.asi-mag.com $\% 2$ Ftravel-document-security-an-airline-perspective $\% 2 \mathrm{~F}$.

94 Ibid.

95 European Commission. (2016). Europeans' views on the priorities of the European Union. Standard Eurobarometer 85-Wave EB85.2—Spring 2016-Report, May 2016 (DirectorateGeneral for Communication), p. 5 o. 
positively. ${ }^{97}$ Calculating the co-variation of public opinion with fines is not possible given the paucity of reliable data.

Political pressure from domestic interests is also likely to affect the number of fines. Competent authorities face public pressure to reduce the number of undocumented travelers, leading to variation in fines. According to an unofficial position of the Minister of Justice of Sweden in 2015, following pressure from the Swedish Aviation Industry Group to lift sanctions so that airlines can transport asylum-seekers, it is "juridically impossible" for Sweden to lift sanctions, as the basis is an EU Directive. ${ }^{98}$ However, according to the Swedish statistics, almost no fines were provided (10 total at Arlanda across a 10 year period). This suggests that political pressure in some cases can reduce, and in other cases increase fines. Business groups may not want restrictive carrier sanction policies, but public officials are apt to express support for them to show they are in control of undocumented travelers. These findings support the hypothesis that "political salience" impacts implementation-variations in political pressures and public opinion will impact the number and amount of fines. ${ }^{99}$ They suggest that the 'salience' or visibility of the issue of carrier sanctions varies across Europe, and by implication the 'risk perception' of undocumented migration is variable. ${ }^{100}$ Differences in the 'salience' of carrier sanctions partly explains their variation across Europe-where the issue is of high salience, statistics are well recorded and carriers are fined heavily, where the issue is of low salience, statistics may be lacking, and/or fines less severe.

\section{Conclusion}

Based on a novel data set this study details trends in carrier sanctions in 10 European states over the time period of 2000-2014. To deal with the unreliability of the data collected, in-depth interviews with key actors and readings of primary and secondary literature were used as additional sources. It is necessary to understand trends in carrier sanctions because of the implications

\footnotetext{
$97 \quad$ Ibid.

98 Radio Sweden, 'Swedish airline industry wants to be able to fly refugees to Sweden', 10 September 2015, http://sverigesradio.se/sida/gruppsida.aspx?programid=2054\&grupp= 3575 \&artikel $=6252800$.

99 Versluis, E., Explaining Variations in Implementation of EU Directives, 8(19) European Integration online Papers (EIOP), (2004), http://eiop.or.at/eiop/texte/2004-2019a.htm.

100 Ibid.
} 
such trends have for the privatization of migration management and effects on human rights. In relation to the number of sanctions levied and their growth or decline, the data indicate that carrier sanctions are variably implemented throughout Europe with differing trends across countries, and it is difficult to tease out the causes and effects of these trends.

These findings raise a number of implications relevant for future work. First, trends in number and amount of sanctions are uneven, and by extension the implementation of legislation is somewhat haphazard and in some cases lacking. The variation is an expression of diverse local policy outcomes (which may be unintended), giving the impression that the implementation of carrier sanctions is incoherent and haphazard. ${ }^{101}$ Such 'incoherence' lends support to the hypothesis that carrier sanctions are in some cases a mostly symbolic control policy (as in Sweden or Switzerland, and in earlier years in Germany), whereas in other cases carrier sanctions are vigorously enforced and have real material value for states, not only symbolic (such as the UK and the Netherlands, and Germany in the later years). ${ }^{102}$ In other words, in some cases we see a large implementation gap between the goals of carrier sanctions and their implementation in practice, in others we see a small or non-existent gap. ${ }^{103}$ These findings raise the question whether states (and carriers) are in control of undocumented migration, and the answer is 'it depends': in some cases the state still plays a strong role in outsourcing migration control through regular and severe enforcement, while in others the state takes a more lenient approach to exacting penalties.

Second, the availability and transparency of carrier sanctions data are severely lacking. Existing sources are hard to obtain, may not be complete, and are not reliable, making it hard to draw a fully comparable and accurate picture of the evolution of carrier sanctions. The lack of statistics is evidence of larger deficiencies in carrier sanctions. ${ }^{104}$ In order to carry out more accurate analyses of carrier sanctions, we need more reliable data. Following Singleton's

101 Lahav, G. 'Immigration and the state: the devolution and privatisation of immigration control in the EU', 24(4) Journal of ethnic and migration studies (1998) 675-694.

102 Hollifield, J.F., P.L. Martin \& P.M. Orrenius, Controlling immigration: a global perspective (third ed.), (Stanford: University Press, 2014); Sassen, S., Losing control?: sovereignty in an age of globalization (New York: Columbia University Press, 1996).

103 Czaika, M. \& H. de Haas, 'The Effectiveness of Immigration Policies'. 39(3) Population and Development Review (2013) 487-508.

104 Gammeltoft-Hansen, 2013 (n. 20), p. 141. 
review of issues related to migration statistics in the EU, a number of recommendations for future work can be made:105

- Based on the current study, the available data is not reliable or comprehensive, and thus of poor quality. Improving the quality of carrier sanctions data is needed to assess their relevance for research, policy, and advocacy purposes.

- Collection of carrier sanction data at the national level should be improved.

- Carrier sanctions data should be regularly recorded, updated, and shared publically at the Eu level.

- Evaluations should be carried out based on the new data in order to assess the implementation and effects of carrier sanctions.

Carrier sanctions legislation is described by many studies as having detrimental effects on fundamental rights and international protection, supporting a near consensus in the literature that carrier sanctions are harmful to asylumseekers and those in need of international protection (see Introduction). The re-shaped relations between states, firms, and individuals represent a decline in the moral, ethical, and legal obligations of states and firms towards populations in need of protection, blurring the lines of who is responsible when abuses occur. Recent work by Gammeltoft-Hansen shows that refugees have a difficult time accessing complaint procedures when harms occur. ${ }^{106}$ Abeyratne argued that while airlines do have responsibilities, states have greater obligations under refugee and international law. ${ }^{107}$ Rodenhauser similarly argues that the activities of carrier personnel can be attributable to the state. ${ }^{108}$ There is also very little transparency and availability of data and practices, making it difficult to determine who is responsible when things go wrong, muddying the ability to determine accountability for abuses. Since "prospects for repealing

105 Singleton, A., Migration and Asylum Data for Policy-making in the European Union: The problem with numbers, Centre for European Policy Studies (CEPS) Paper in Liberty and Security in Europe 89 (Brussels: CEPS, 2016).

106 Gammeltoft-Hansen, T., The Practice of Shared Responsibility in relation to Private Actor Involvement in Migration Management, University of Amsterdam, SHARES Research Paper 83 (Amsterdam: Amsterdam Center for International Law, 2016)(www.shares project.nl).

107 Abeyratne, R.I.R., 'Air Carrier Liability and State Responsibility for the Carriage of Inadmissible Persons and Refugees', 10(4) International Journal of Refugee Law (1998) 675-687.

108 Rodenhauser, T., 'Another Brick in the Wall: Carrier Sanctions and the Privatization of Immigration Control', 26(2)International Journal of Refugee Law (2014) 223-247. 
carriers' liability legislation are poor", ${ }^{109}$ alternative mechanisms to hold harmful state and non-state actors accountable must be developed. 'Lifting the corporate veil' is one way to improve transparency in carrier practice, ${ }^{110}$ but according to the secondary literature and the interpretation of the evidence here, much more needs to be done in order to address the inconsistencies in policy implementation and harms towards those in seek of protection produced by carrier sanction legislation.

Based on key questions raised by industry and humanitarian organizations about carrier sanctions, updated quality data can assist in determining:111

- Whether carrier sanctions are an appropriate policy tool;

- The degree of diligence expected from carriers;

- Who is responsible when harms occur;

- If carrier sanctions are compatible with states' obligations.

Finally, this study raises a number of concerns. Understanding the dynamics of carrier sanctions is important, as carrier sanctions are known to have effects undermining fundamental rights and refugee protection. Decisionmakers in European countries are unable to diagnose the effects of carrier sanctions policies due to limited and unreliable data. ${ }^{112}$ Explaining when and where carrier sanctions may play a role can help service providers in identifying how to approach carriers and states in order to improve standards of protection and respond to the potentially harmful effects of carrier sanctions.

\footnotetext{
109 Nicholson, 1997 (n. 17), p. 634.

110 Gammeltoft-Hansen, 2013 (n. 20).

111 IRU, Round Table on Carriers' Liability Related to Illegal Immigration, Minutes of the meeting of 30 November 2001, jointly organised by the International Road Transport Union (IRU), the European Community Shipowners Association (ECSA), the International Air Transport Association (IATA) and the International Union of Railways (UIC) in close cooperation with the European Commission (Brussels: International Road Transport Union (IRU), 2001).

112 Singleton, 2016 (n. 105).
} 